\title{
Examination of the Relation between Academic Procrastination and Time Management Skills of Undergraduate Students in Terms of Some Variables
}

\author{
Gürbüz Ocak ${ }^{1}$, Serkan Boyraz ${ }^{1,2}$ \\ ${ }^{1}$ Curriculum and Instruction Department, Afyon Kocatepe University, Afyonkarahisar, Turkey \\ ${ }^{2}$ Lecturer of English at Aksaray University, Aksaray, Turkey \\ Correspondence: Serkan Boyraz, Lecturer of English at Aksaray University, Aksaray, Turkey; PhD. Student in \\ Curriculum and Instruction Department at Afyon Kocatepe University, Afyonkarahisar, Turkey
}

Received: January 20, 2016 Accepted: February 22, 2016 Online Published: February 27, 2016

doi:10.11114/jets.v4i5.1313

URL: http://dx.doi.org/10.11114/jets.v4i5.1313

\begin{abstract}
Academic procrastination is seen to be quite common among undergraduates and time management is thought to be one of the possible reasons of it. Two surveys, academic procrastination and time management, were given to 332 undergraduate students in this correlational research. Students' academic procrastination is explained through frequencies and percentages and a correlation is questioned between academic procrastination and time management. Regression analysis is used to find out if time management predicts academic procrastination in a statistically significant way. Besides, students' level of time management (low, medium, high) is examined and covariance analysis has been carried out to see if time management level and gender, time management level and housing type (private or state dormitory or house), time management level and their major and time management level and where they live have a common effect on academic procrastination. Results indicate that students are generally indecisive about their behaviors of procrastination in academic tasks and are in middle level in terms of time management skills. There is a moderate level, negative sided and statistically significant correlation between academic procrastination and time management. Not a common effect of mentioned above variables is seen.
\end{abstract}

Keywords: academic procrastination, time management, university students

\section{Introduction}

People's delaying the things they are supposed to do is a very old human behavior and struggle for time management by people dates back to ancient Egyptian hieroglyphics even 1400 B.C. In 1750s when time and using it effectively became key terms due to developed production process, Dr. Samuel Johnson who prepared the first comprehensive American English dictionary (1751) described "procrastination" as "“"The folly of allowing ourselves to delay what we know cannot be finally escaped" (as cited in Janssen, 2015, p. 2) and researches point out people procrastinate in six different aspects/domains of life: academic and work, everyday routines and obligations, health, leisure, family and partnership, and social contacts (Janssen, 2015, s. 15) Individuals might procrastinate various things and this can be delighting at the beginning.

For the students of today, the amount of information to be learned increases day by day together with the number and accessibility of distractors like online games, social media, game platforms etc. which might steal their time. Current distractors like social media have become an addiction among undergraduates (Andreassen, 2015) and this might be an important factor in their academic procrastination. Researches reveal that students do not take notice of short periods of time and as a result are overwhelmed with the common cliché "scarcity of time" and they should be warned that if they plan these short periods of time well then the other tasks will be easier (Bashir, Bashir, \& Nazir, 2015).

\section{Literature Review}

Academic procrastination which is a kind of procrastination includes delaying school based tasks and can be described as procrastinating academic tasks due to some reason (Akbay \& Gizir, 2010, p. 60). Assignments that are not done or tasks that are not fulfilled can cause negative consequences such as disturbed sleep, stress, anxiety to manage time effectively and might result in giving up or partially fulfilling the task (Deniz \& Akdoğan, 2014, p. 30).

Klingsieck (2013) describes academic procrastination as postponing an academic task that is to be done voluntarily or 
necessarily and/or which is personally important although a person is aware of possible positive short-term consequences will be overwhelmed by long-term negative ones. In another way, it is described as delaying the completion of an academic task/assignment or postponing to study for the examinations and this is very common among the students all over the world (Kim \& Seo, 2015, p. 26). Although it is common nowadays, it not a new issue. Ellis and Knaus (1977) estimate that $95 \%$ of college students engage in procrastination and their tendency increases together with the time they spend in college (as cited in Solomon \& Rothblum, 1984). The prevalence of this behavior which is performed consciously despite being aware of negative consequences was found to be around $20 \%$ (Harriot \& Ferrari, 1996; p. 611); in another study 85\% (Schouwenburg \& Groenewoud, 2001) while another research predicts it is between $85-90 \%$ (Steel, 2007, p. 65). In their study in which they examine academic procrastination behavior of Turkish undergraduate students, Ozer, Demir ve Ferrari (2009) state that 405 students (52\%) out of 784 perform academic procrastination while $379(48 \%)$ do not. Besides this prevalence, students that procrastinate unnecessarily may not even be aware of it and feel disturbed (Lindblom-Ylänne, Saariaho, Inkinen, Anne-Haarala-Muhonen, \& Hailikari, 2015) or some of them may not be volunteered to decrease the number of it (Grunschel \& Schopenhauer, 2015). The reason why this behavior is more common among undergraduates rather than primary, secondary and high school students is the more flexible learning environment (You, 2015).

Academic procrastination is studied a lot due to its being common and having many negative aspects. Theories and findings related to this behavior are divided into two categories. One of them emphasizes the features related to task performance or realization of the goals while the other highlights individual differences and uses personal features to explain academic procrastination (Johnson \& Bloom, 1995, p. 127). Researchers suggest various possible predictors like a tendency toward self-handicapping, low selfesteem, low academic self-efficacy, fear of failure, and distorted perceptions of available and required time to complete tasks as cognitive variables; anxiety, depression, and worry as emotional and lower conscientiousness and higher neuroticism as personality variables (Rabin, Fogel, \& Nutter-Upham, 2011). According to findings of a meta-analysis that includes 121 studies, the strongest average correlations were those with conscientiousness $\left(r_{\text {mean }}=-.63\right)$ and self-efficacy $\left(r_{\text {mean }}=-.44\right)$; anxiety and depression were moderately related $\left(r_{\text {mean }}=.21\right.$ and .30 , respectively); performance outcomes, such as grade point average, were negatively related $\left(r_{\text {mean }}=\right.$ -.28) (Van Eerde, 2003). According to Dietz, Hofer and Fries (2007) procrastination might be regarded as a failure in self regulation and students with a high level of procrastination should take the adventage of time management strategies to reach their academic goals. There are other studies in the literature showing ineffective time management or lack of time management skilss as a possible reason of procrastination (Ajayi \& Osiki, 2008; Díaz-Morales \& Ferrari, 2015; Pang \& Han, 2009; Swart, Lombard \& Jager, 2010).

Time management is another common and one of the most important problems in the modern world. Examining many various definitions in the literature, Claessens, Van Eerde, Rutte and Roe (2007) define the time management as behaviours that intend to use the time effectively while performing certain goal directed activities which emphasize that the use of time is not the aim itself but it is like a "tool" while fulfilling a work or academic task. Successful time management which can be explained as realizing the best use of time in the highest level in a way that will provide productivity, balance and self-satisfaction can be really compelling because of foreseeing an insufficient amount of time to complete their duties/responsibilities or preferring the completion of short-term tasks with less gain to long-term but with more gain ones (Oettingen, Kappes, Guttenberg, \& Gollwitzer, 2015). Time management is simply more than planning the time; it also includes a high level of awareness in terms of use of time and determining, planning, monitoring and organizing of goals and (Van Eerde, 2015, p. 313). Kirillov, Tanatova, Vinichenko \& Makushkin (2015) group people into three in terms of their approach to time management: those who see it i) as necessary for success; ii) unnecessary as everything takes it course and iii) important but do not have enough concentration and sustainability to change. Undergraduates also fall in one of these groups according to them.

\section{Problem of the Research}

According to the findings in the literature, academic procrastination behavior is common among undergraduates and insufficient time management skills is thought to be one of the possible reasons of it. This is the problem of this research. The sub-problems are as follows:

1. What is the current situation of undergraduates in terms of academic procrastination?

2. What is the current level (low, moderate, high) of undergraduates in terms of their time management skills?

3. Is there a statistically significant relation between undergraduates' academic procrastination behaviors and time management skills?

4. Do the undergraduates' time management skills predict their academic procrastination?

5. Is there a common effect of the following variables on students' academic procrastination?

a. Time management level and gender

b. Time management level and their faculty 
c. Time management level and their housing type

d. Time management level and their age

e. Time management level and where they live

\section{Method}

As the aim of the research is to find out if there is a relation between undergraduates' academic procrastination behaviors and time management skills, the study employs a correlational research method. The aim of this kind of research is to determine the relationship between variables in order to have a better understanding for important topics. The difference between experimental and correlational research in which it is common to investigate the relation between two variables while it possible to look for more is not manipulating the variables (Fraenkel \& Wallen, 2006, p. 335-336).

\subsection{Data Collection and Analysis}

Two scales were used in the research to collect the data. Firstly, academic procrastination scale which is developed by Ocak and Bulut (2015) was used in order to determine undergraduates' academic procrastination behaviors. Ocak and Bulut state that their scale has four sub-dimensions: irresponsibility (19 items); perceived features of the academic task (10 items); negative perceptions towards lecturers (5 items) and academic perfectionism (4 items). These four dimensions explain $53.61 \%$ of the total variance. Reliability of the scale is 0.947 . In this study, the scale shows a four sub-dimension form again but the number of items is different. In the same order of sub-dimensions given above, the number of items is $16,11,5$ and 6 and total variance explained is $51.54 \%$. The reliability of the scale is 0.923 .

Secondly, time management questionnaire which is developed by Britton and Glynn (1989) and adapted into Turkish by Alay and Koçak (2002) is used to investigate undergraduates' time management skills. A total of $35 \%$ variance is explained by 27 items in total and in three sub-dimensions, namely: time planning (16 items; explained variance: 20\%); time attitudes ( 7 items; explained variance: $9 \%)$ and time wasters (4 items; explained variance: $6 \%)$. In this study, there are three sub-dimensions again: 20 items in the first sub-dimension; 4 in second and 3 in the third and a total of $36.85 \%$ of the variance is explained. The reliability of the scale is 0.73 .

The total scores of the scales were used in statistical analysis and scores in sub-dimensions were not used. Normal distribution of the data set is examined through the significance of normality tests, skewness and kurtosis values (being close to zero) and mode-median-mean values' being close to each other. The data from 342 participants was not distributed normally in time management questionnaire, so extreme values are excluded from analysis to provide normal distribution. Normal distribution was achieved after excluding 10 extreme values (5 low and 5 high extreme values) in the time management questionnaire. Frequencies and percentages, simple linear correlation, simple regression and two-way anova are the statistical analysis used in the study. If there is a linear relationship between the two variables which is a precondition to do regression analysis (Can, 2014) was checked through scatter diagram and linear relation was seen.

\subsection{Universe and Sample}

The universe of the research includes undergraduates studying at Aksaray University central campus in five faculties (Engineering, Economics and Administrative Sciences (EAS), Education, Science and Literature (S\&L) and Tourism) in 2015-2016 academic year. Random sampling was used as the sampling method. This kind of sampling includes using the sample you can directly reach at a moment (Walliman, 2006, p. 78). The table of sampling numbers which is developed by Yazıcıŏglu and Erdoğan (2011) was used in order to determine required number of samples. According to it, the number of samples for $\alpha=0.05$ sampling error should be 370 when there are ten thousand participants (nearly ten thousand students in this research) in the universe. A total of 391 participants were reached but due to missing answers (and normality) only 332 were used in statistical analysis. Demographic information of the participants are given in Table 1 below: 
Table 1. Demographics of the Participants

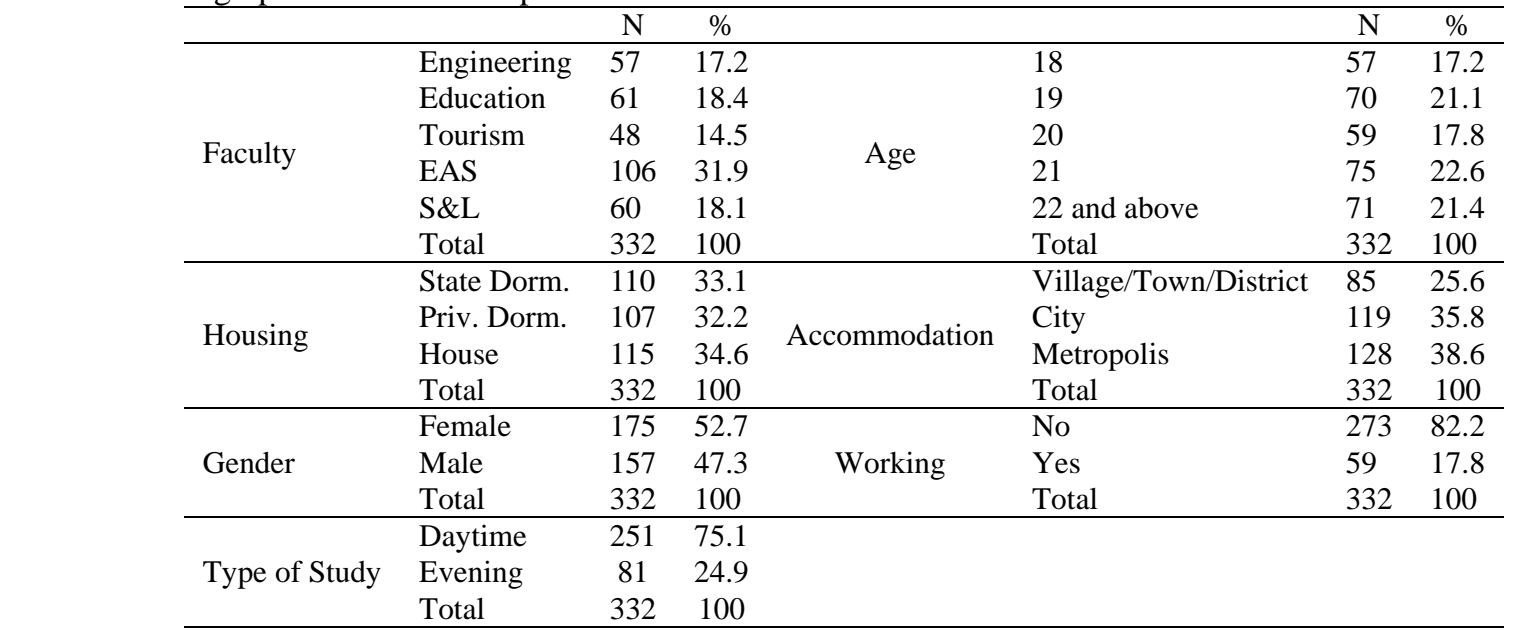

\section{Findings}

Findings related to the sub-problems of the study are given below.

I. Sub-problem: What is the current situation of undergraduates in terms of academic procrastination?

In order to show current situation of undergraduates in terms of their academic procrastination behaviors, their scores were given in frequencies and percentages and the mean was calculated. It is important to note that the higher scores from the academic procrastination scale indicate more procrastination or more tendency for procrastination. Mean for each item was calculated and result was drawn depending on this intervals: 1.00-1.79: Strongly Disagree; 1.80-2.59: Disagree; 2.60-3.39: Indecisive; 3.40-4.19: Agree and 4.20-5.00: Strongly Agree. According to mean scores of each item in the scale, only two results were indicated: Disagree (D) or Indecisive (Ind).

Findings related to this sub-problem are given below. Table 2 shows descriptive statistics on the first sub-dimension of academic procrastination scale which is "responsibility":

Table 2. Descriptive Statistics on Responsibility Sub-Dimension of Academic Procrastination Scale

1- I procrastinate my academic tasks despite not having a more important thing to do.

2- I procrastinate my academic tasks to the last minute as I am an unplanned person.

3- I procrastinate the tasks like doing the assignments or studying for an exam because I have a low level of concentration for studying.

4- I procrastinate studying for the exams to the last day because of unnecessary reasons.

5- I procrastinate my academic tasks to another day as there is not a motivating force that will activate me.

6- I leave fulfilling academic tasks to the last day as I do not arrange them according to their priorities.

7- I am not willing to do the assignments even when the due is close.

8- I leave doing my academic tasks to the last minute since I am not motivated to do them.

9- I spend most of my time on entertaining activities instead of studying although I regret.

10 - I study the exams on the last day because of insufficient motivation.

11- I am a person who says her/himself I will start studying this time but doesn't.

12- I am a time-waster.

13- I leave the academic tasks that require much effort to the last minute.

14- I leave fulfilling academic tasks to the last minute as I spend much time on social activities like watching movie, playing games, etc.

15- I do even my important academic tasks in the last minute.

16- I can't motivate myself when I start doing my academic tasks.

\begin{tabular}{cccccccc} 
& 1 & 2 & 3 & 4 & 5 & $\mathrm{X}$ & Result \\
$\mathrm{F}$ & 120 & 65 & 52 & 59 & 36 & 2.48 & $\mathrm{D}$ \\
$\%$ & 36.1 & 19.6 & 15.7 & 17.8 & 10.8 & & \\
$\mathrm{~F}$ & 94 & 89 & 47 & 67 & 35 & 2.58 & $\mathrm{D}$ \\
$\%$ & 28.3 & 26.8 & 14.2 & 20.2 & 10.5 & & \\
$\mathrm{~F}$ & 83 & 86 & 53 & 75 & 35 & 2.68 & Ind \\
$\%$ & 25.0 & 25.9 & 16.0 & 22.6 & 10.5 & & \\
$\mathrm{~F}$ & 83 & 91 & 48 & 68 & 42 & 2.68 & Ind \\
$\%$ & 25.0 & 27.4 & 14.5 & 20.5 & 12.7 & & \\
$\mathrm{~F}$ & 82 & 81 & 61 & 65 & 43 & 2.72 & Ind \\
$\%$ & 24.7 & 24.4 & 18.4 & 19.6 & 13.0 & & \\
$\mathrm{~F}$ & 80 & 102 & 555 & 57 & 38 & 2.61 & Ind \\
$\%$ & 24.1 & 30.7 & 16.6 & 17.2 & 11.4 & & \\
$\mathrm{~F}$ & 80 & 85 & 46 & 76 & 45 & 2.76 & Ind \\
$\%$ & 24.1 & 25.6 & 13.9 & 22.9 & 13.6 & & \\
$\mathrm{~F}$ & 83 & 84 & 53 & 68 & 44 & 2.72 & Ind \\
$\%$ & 25.0 & 25.3 & 16.0 & 20.5 & 13.3 & & \\
$\mathrm{~F}$ & 89 & 83 & 45 & 64 & 51 & 2.71 & Ind \\
$\%$ & 26.8 & 25.0 & 13.6 & 19.3 & 15.4 & & \\
$\mathrm{~F}$ & 54 & 98 & 54 & 84 & 42 & 2.89 & Ind \\
$\%$ & 16.3 & 29.5 & 16.3 & 25.3 & 12.7 & & \\
$\mathrm{~F}$ & 64 & 89 & 63 & 68 & 48 & 2.84 & Ind \\
$\%$ & 19.3 & 26.8 & 19.0 & 20.5 & 14.5 & & \\
$\mathrm{~F}$ & 83 & 88 & 71 & 49 & 41 & 2.63 & Ind \\
$\%$ & 25.0 & 26.5 & 21.4 & 14.8 & 12.3 & & \\
$\mathrm{~F}$ & 85 & 93 & 75 & 47 & 32 & 2.54 & $\mathrm{D}$ \\
$\%$ & 25.6 & 28.0 & 22.6 & 14.2 & 9.6 & & \\
$\mathrm{~F}$ & 64 & 117 & 54 & 59 & 38 & 2.67 & Ind \\
$\%$ & 19.3 & 35.2 & 16.3 & 17.8 & 11.4 & & \\
$\mathrm{~F}$ & 86 & 109 & 69 & 44 & 24 & 2.43 & $\mathrm{D}$ \\
$\%$ & 25.9 & 32.8 & 20.8 & 13.3 & 7.2 & & \\
$\mathrm{~F}$ & 73 & 107 & 74 & 56 & 22 & 2.54 & $\mathrm{D}$ \\
$\%$ & 22.0 & 32.2 & 22.3 & 16.9 & 6.6 & & \\
\hline & & & & & & &
\end{tabular}


The items number 1 (I procrastinate my academic tasks despite not having a more important thing to do.) and 2 (I procrastinate my academic tasks to the last minute as I am an unplanned person.) that participants do not agree are negative items in meaning but carry a positive attitude or tendency towards academic procrastination. Participants do not agree with two items number $13(X=2.54)$ and $15(X=2.43)$ which are about showing academic procrastination behavior for academic tasks that require much effort or which are important. Another item that participants disagree is number 16 which is about having difficulty in self-motivating for academic tasks. On all other 11 items, participants are indecisive.

The second sub-dimension of the academic procrastination scale is perceived quality of the academic task. There are 11 items in this dimension and statistical finding about them are given below in Table 3:

Table 3. Descriptive Statistics on Perceived Quality of the Academic Task Sub-Dimension of Academic Procrastination Scale

17- I procrastinate my responsibilities like studying the lessons or preparing for an exam because of failure concerns.

18- It takes a long time even to start studying.

19- I plan how much time I will spend on academic tasks in advance.

20- I quickly start doing assignments that require much time.

21- I quickly start and finish academic tasks that are easy to do.

22- I do the academic tasks that require thinking over on time as I love them.

23- I do the assignments that I can handle on time.

24- I show enough effort to hand my assignment on time.

25- I quickly do the assignments that I enjoy while doing.

26- I quickly start doing academic tasks if they are enjoyable to do.

27- I do the academic tasks that attract me on time.

The results show that participants $(\mathrm{N}=332)$ disagree with 6 items and are indecisive about 5 items out of 11 . The item with lowest mean was number 25 that says "I quickly do the assignments that I enjoy while doing." $(\mathrm{X}=2.21)$ and items number 26 and 27 that are close in meaning to it are also among the ones with lowest means. Another item that participants disagree is number $24(\mathrm{X}=2.37)$ that tells "I show enough effort to hand my assignment on time." The other items that participants do not agree are numbers 25, 26 and 27 all of which are about the feeling that the assignment gives and close in meaning show tendency towards academic procrastination.

The third sub-dimension of the academic procrastination scale is negative perception towards the lecturer. There are 5 items in this dimension and statistical finding about them are given below in Table 4.

Table 4. Descriptive Statistics on Negative Perception towards the Lecturer Sub-Dimension of Academic Procrastination Scale

28- I do the academic tasks on time even if they are compelling.

29- I do the academic tasks on time even if they are difficult.

30- I procrastinate academic tasks that are given by a lecturer who I think will not teach me something.

31- I procrastinate academic tasks that are given by an oppressive lecturer.

32- I procrastinate academic tasks that are given by lecturers who waste the time instead of teaching the students to the last minute.

There are two items in which participants' mean is just above three. The mean of item number 32 that tells "I procrastinate academic tasks that are given by lecturers who waste the time instead of teaching the students to the last minute." is 3.05 and the mean of item number 34 which is close in meaning to number 32 and tells "I procrastinate the assignments given by lecturers who do not give enough importance to their lectures to the last minute." is 3.06 . The other items with high means are number $31(\mathrm{X}=2.91)$ and $33(\mathrm{X}=2.95)$ and all these four items are related to the lecturers. 
The fourth sub-dimension of the academic procrastination scale is academic perfectionism. There are 6 items in this dimension and statistical finding about them are given below in Table 5 .

Table 5. Descriptive Statistics on Academic Perfectionism \& Reaction to Teacher Sub-Dimension of Academic Procrastination Scale

33- I don't do the assignments given by lecturers that I don't like on time.

34- I procrastinate the assignments given by lecturers who do not give enough importance to their lectures to the last minute.

35- I am late for studying other exams as I study over and over for an exam.

36- There have been risks of late returns as I do corrections on assignments again and again.

37- I keep doing the assignments to the last day as I want to do them in the best way.

38- Even thinking of doing the best procrastinates starting to study.

$\begin{array}{cccccccc} & 1 & 2 & 3 & 4 & 5 & \mathrm{X} & \text { Result } \\ \mathrm{F} & 58 & 70 & 85 & 68 & 51 & 2.95 & \text { Ind } \\ \% & 17.5 & 21.0 & 25.6 & 20.5 & 15.4 & & \\ \mathrm{~F} & 51 & 83 & 58 & 75 & 65 & 3.06 & \text { Ind } \\ \% & 15.4 & 25.0 & 17.5 & 22.6 & 19.6 & & \\ \mathrm{~F} & 55 & 74 & 85 & 69 & 49 & 2.95 & \text { Ind } \\ \% & 16.6 & 22.3 & 25.6 & 20.8 & 14.862 & & \\ \mathrm{~F} & 63 & 92 & 83 & 66 & 28 & 2.71 & \text { Ind } \\ \% & 19.0 & 27.7 & 25.0 & 19.9 & 8.4 & & \\ \mathrm{~F} & 56 & 97 & 73 & 75 & 31 & 2.78 & \text { Ind } \\ \% & 16.9 & 29.1 & 22.0 & 22.6 & 9.3 & & \\ \mathrm{~F} & 52 & 96 & 76 & 71 & 37 & 2.83 & \text { Ind } \\ \% & 15.7 & 28.9 & 22.9 & 21.4 & 11.1 & & \end{array}$

The results show that participants are indecisive with all the 6 items in this sub-dimension. The highest mean is 3.06 in item number 34 that is about the lecturer attitude towards his/her own lesson. The other items' mean scores are also relatively high and close to three. Last four items in this category is about perfectionism and tries to present if search for better results in procrastination.

II. Sub-Problem: What is the current level (low, moderate, high) of undergraduates in terms of their time management skills?

Participants' score means in time management questionnaire were calculated to present their level of time management and findings related to it were given in Table 6.

Table 6. Time Management Level of Participants

\begin{tabular}{lcc}
\hline Level & $\mathrm{N}$ & $\%$ \\
\hline Low & 21 & 6.3 \\
\hline Intermediate & 294 & 88.6 \\
\hline High & 17 & 5.1 \\
\hline Total & 332 & 100 \\
\hline
\end{tabular}

Participants are classified into three categories as low, intermediate and high depending on their total score in time management questionnaire. As can be seen in the table, a big majority of the participants have intermediate $(\mathrm{N}=294)$, while 21 have low and 17 have high level of time management skills.

III. Sub-Problem: Is there a statistically significant relation between undergraduates' academic procrastination behaviors and time management skills? Findings related to this problem is given below in Table 7 .

Table 7. The Relation between Academic Procrastination and Time Management

\begin{tabular}{lcc}
\hline & Correlation Coefficient & $\mathrm{p}$ \\
(r) & -.309 & .000 \\
Academic Procrastination & -309 & \multirow{2}{*}{ Time Management }
\end{tabular}

The result of simple linear correlation analysis carried out to see if there was a statistically significant correlation between academic procrastination and time management shows that there is a significant $(\mathrm{p}=.000 ; \mathrm{p}<.05)$ and moderate level and negative sided ( $\mathrm{r}=-.309)$ relation between the two variables. This result indicates that increase in time management scores is likely to come with decrease in academic procrastination scale scores.

IV. Sub-Problem: Do the undergraduates' time management skills predict their academic procrastination?

The relation between time management and academic procrastination is questioned here and findings are given below in Table 8 .

Table 8. Predictive Role of Time Management on Academic Procrastination

\begin{tabular}{lccccc}
\hline & Sum of Squares & Df & Sum of Squares & F & p \\
\hline Regression & 20640.373 & 1 & 20640.373 & & \\
Constant & 194841.516 & 330 & 590.429 & 34.958 & .000 \\
Total & 215481.889 & 331 & & & \\
$\mathrm{R}=.309 ; \mathrm{R}^{2}=.096 ;$ Adjusted $\mathrm{R}^{2}=.093$ & & & &
\end{tabular}

Simple regression analysis were done to see if time management was a statistically significant predictive of academic procrastination and results show that there is significant relation between the two $\left(R=0.309 ; R^{2}=0.096\right)$ and time 
management is a significant predictor of academic procrastination $\left(F_{(1-330)}=34.958 ; p=.000 ; p<.05\right)$. Time management predicts 9.6 per cent of academic procrastination.

V. Sub-Problem: Is there a common effect of time management and other variables (gender, faculty, housing, accommodation) on academic procrastination?

Findings related to this sub-problem are given in Table 9.

Table 9. Analysis on the Common Effect of Variables on Academic Procrastination

\begin{tabular}{lccccc}
\hline Variables & Sum of Squares & Df & Mean of Squares & F & p \\
\hline Time Management*Gender & 2636.623 & 2 & 1318.312 & 2.130 & .120 \\
Time Management*Housing & 2095.824 & 4 & 523.956 & .844 & .498 \\
Time Management*Faculty & 5690.492 & 8 & 711.311 & 1.147 & .331 \\
Time Management* Accommodation & 5473.855 & 4 & 1368.464 & 2.205 & .068 \\
\hline
\end{tabular}

Two-way Anova results show that there was not a statistically significant common effect of the given variables on the academic procrastination ( $p>.05)$.

\section{Results and Discussion}

According to the results, undergraduates are seen to have moderate level of tendency for academic procrastination. Lack of motivation and attraction are two major reasons for academic procrastination as the participants are not volunteered to do the academic tasks even if they are enjoyable and attractive. Similarly, Klassen, Krawchuk and Rajani (2008) and Klassen and Kuzucu (2009) state the existence of a relation between motivation and procrastination. Besides, Lee (2005) explains that students who motivate themselves better show less tendency towards academic procrastination. Sirin (2011) and Stewart, Stott and Nuttall (2015) also indicate that academic motivation is a predictor of the academic procrastination behavior. Among the highest scores which indicate higher tendency towards academic procrastination are items related to lecturers. Participants are tended to show more tendency on procrastination when they think the lecturers do not give enough importance to their lectures or intend to teach their students. Similarly, they are not willing to fulfill academic tasks given by lecturers who are oppressive or of whom they think they can't learn anything. In the light of these findings, lecturer attitudes and behaviors can be said to effect the academic procrastination importantly. Participants are generally in moderate level in terms of their time management skills and their mean in the time management questionnaire is 80.80 (standard deviation: 11.41). Similarly, Zekioğlu, Erdoğan and Türkmen (2015) find time management score mean as 81.10 (standard deviation: 14.69) of 74 sports students and Yavaş, Öztürk, Açıkel and Özer (2012) find 79.06 (standard deviation: 14.07) of 420 medical students. There is a statistically significant and moderate level negative relation between academic procrastination and time management. As a result, students with a higher time management skill might be expected to show less tendency towards academic procrastination. However, Glick and Orsillo (2015) state that although undergraduates with a better time management skill fulfill more academic tasks, there is not a statistically significant difference between the two groups in terms of academic procrastination. In their study on undergraduates, similarly, Miqdadi, ALMomani, Masharqa and Elmousel, (2014) explain that the minority of students with a better time management are not successful and the majority of them who show academic procrastination are more successful students although they start doing the tasks close to due. We can infer that even though effective time management decreases academic procrastination, it does not guarantee the success; students with academic procrastination behavior can be successful also. Another finding indicates that the time management predicts academic procrastination in a statistically significant way as much as nearly ten per cent. Participants are generally in moderate level in terms of their time management skills. There is not a common effect of time management together with gender, housing, faculty and accommodation on academic procrastination.

\section{References}

Ajayi, A. I., \& Osiki, P. M. (2008). Procrastination among the undergraduates in a Nigerian university: Implications for time management. International Business Management, 2(4), 126-131.

AKBAY, S. E., \& GİZİR, C. A. (2010). Cinsiyete göre üniversite öğrencilerinde akademik erteleme davranış1: akademik güdülenme, akademik özyeterlik ve akademik yükleme stillerinin rolü. Mersin Üniversitesi Eğitim Fakültesi Dergisi, 6(1), 60-78.

Alay, S., \& Koçak, S. (2002). Validity and reliability of time management questionnaire. Hacettepe Üniversitesi Ĕgitim Fakültesi Dergisi, 22, 9-13.

Andreassen, C. S. (2015). Online social network site addiction: a comprehensive review. Technology and Addiction, 2(2), 175-184. http://dx.doi.org/10.1007/s40429-015-0056-9

Bashir, S., Bashir, Z., \& Nazir, M. (2015). Time management and its application in academic life: a study of omani students at dhofar university, sultanate of oman. Linguistics, 4(2), 154-159. 
Can, A. (2014). SPSS ile bilimsel araştırma sürecinde nicel veri analizi (2. ed.). Ankara: Pegem.

Claessens, B. J., Eerde, W. V., Rutte, C. G., \& Roe, R. A. (2007). A review of the timemanagement literature. Personnel Review, 36(2), 255-276. http://dx.doi.org/10.1108/00483480710726136

Deniz, M. E., \& Akdoğan, A. (2014). Farklı depresyon anksiyete stres düzeylerine sahip üniversite öğrencilerinin akademik erteleme davranışlarının incelenmesi. Psikolojik Danışmanlık ve Eğitim Dergisi, 1(1), 28-44.

Díaz-Morales, J. F., \& Ferrari, J. R. (2015). More Time to Procrastinators: The Role of Time Perspective. In M. Stolarski, W. v. Beek, \& N. Fieulaine (Eds.), Time perspective theory; review, research and application (pp. 305-322). London: Springer International Publishing.

Dietz, F., Hofer, M., \& Fries, S. (2007). Individual values, learning routines and academic procrastination. British Journal of Educational Psychology, 77(4), 893-906. Retrieved from http://dx.doi.org/10.1348/000709906x169076

Eerde, W. V. (2015). Time management and procrastination. In The Psychology of Planning in Organizations: Research and Applications (pp. 312-333). New York: Routledge.

Field, A. (2009). Discovering statistics using SPSS (and sex and drugs and rock 'n' roll) (3. ed.). London: SAGE.

Fraenkel, J. R., \& Wallen, N. E. (2006). How to design and evaluate research in eduation. San Francisco: McGrow Hill.

Glick, D. M., \& Orsillo, S. M. (2015). An investigation of the efficacy of acceptance-based behavioral therapy for academic procrastination. Journal of Experimental Psychology, 144(2), 400-409. doi:http://dx.doi.org/10.1037/xge0000050

Grunschel, C., \& Schopenhauer, L. (2015). Why are students (not) motivated to change academic procrastination?: an investigation based on the transtheoretical model of change. Journal of College Student Development, 187-200. http://dx.doi.org/10.1353/csd.2015.0012

Harriott, J. S., \& Ferrari, J. R. (1996). Prevalence of procrastination among samples of adults. Psychological Reports, 78(2), 611-616. http://dx.doi.org/10.2466/pr0.1996.78.2.611

Janssen, J. (2015). Academic procrastination: prevalence among high school and undergraduate student and relationship to academic achievement (doktora tezi). Georgia State University.

Johnson, J. L., \& Bloom, A. M. (1995). An analysis of the contribution of the five factors of personality to variance in academic procrastination. Personal Individual Differences, $18(1), \quad 127-133$. http://dx.doi.org/10.1016/0191-8869(94)00109-6

Kim, K. R., \& Seo, E. H. (2015). The relationship between procrastination and academic performance: A meta-analysis. Personality and Individual Differences, 82, 26-33. doi:http://dx.doi.org/10.1016/j.paid.2015.02.038

Kirillov, A. V., Tanatova, D. K., Vinichenko, M. V., \& Makushkin, S. A. (2015). Theory and practice of time-management in education. Asian Social Science, 11(19), 193-204.

Klassen, R. M., \& Kuzucu, E. (2009). Academic procrastination and motivation of adolescents in Turkey. Educational Psychology, 29(1), 69-81. doi:http://dx.doi.org/10.1080/01443410802478622

Klassen, R. M., Krawchuk, L. L., \& Rajani, S. (2008). Academic procrastination of undergraduates: Low self-efficacy to self-regulate predicts higher levels of procrastination. Contemporary Educational Psychology, 33, 915-931. http://dx.doi.org/10.1016/j.cedpsych.2007.07.001

Klingsieck, K. (2013). Procrastination when good things don't come to those who wait. European Psychologist, 18(1), 24-34. http://dx.doi.org/10.1027/1016-9040/a000138

Lee, E. (2005). The relationship of motivation and flow experience to academic procrastination in university students. The Journal of Genetic Psychology, 166(1), 5-15. doi:http://dx.doi.org/10.3200/GNTP.166.1.5-15

Lindblom-Ylänne, S., Saariaho, E., Inkinen, M., Anne-Haarala-Muhonen, \& Hailikari, T. (2015). Academic procrastinators, strategic delayers and something betwixt and between: An interview study. Frontline Learning Research. http://dx.doi.org/10.14786/flr.v3i2.154

Miqdadi, F. Z., ALMomani, A. F., Masharqa), M. T., \& Elmousel, N. M. (2014). 2014. ASEE 2014 Zone I Conference (pp. 1-5). Bridgpeort, CT: University of Bridgeport.

Ocak, G., \& Bulut, R. (2015). Akademik erteleme ölçeği: Geçerlik ve güvenirlik çalışması. International Journal of Educational Sciences and Research, 1(1), 109-120. 
Oettingen, G., Kappes, H. B., Guttenberg, K. B., \& Gollwitzer, P. M. (2015). Self-regulation of time management: Mental contrasting with implementation intentions. European Journal of Social Psychology, 45, 218-229. http://dx.doi.org/10.1002/ejsp.2090

Ozer, B. U., Demir, A., \& Ferrari, J. R. (2009). Exploring academic procrastination among turkish students: possible gender differences in prevalenceand reasons. THE JOURNAL OF SOCIAL PSYCHOLOGY, 149(2), 241-257. http://dx.doi.org/10.3200/SOCP.149.2.241-257

Pang, W. G., \& Han, G. N. (2009). Study on the Popularity and Causes of Academic Procrastination of Chinese Undergraduates. Tsinghua Journal of Education, 6, 1-13.

Rabin, L. A., Fogel, J., \& Nutter-Upham, K. E. (2011). Academic procrastination in college students: The role of self-reported executive function. Journal of Clinical and Experimental Neuropsychology, 33(3), 344-357. Retrieved from http://dx.doi.org/10.1080/13803395.2010.518597

Schouwenburg, H. C., \& Groenewoud, J. T. (2001). Study motivation under social temptation: Effects of trait procrastination. Personality and Individual Differences, 30(2), 229-240. Retrieved from http://dx.doi.org/10.1016/s0191-8869(00)00034-9

Solomon, L. J., \& Rothblum, E. D. (1984). Academic procrastination: frequency and cognitive -behavioral correlates. Journal of Counseling Psychology, 31(4), 503-509.

Steel, P. (2007). The nature of procrastination: a meta-analytic and theoretical review of quintessential self-regulatory failure. Psychological Bulletin, 133(1), 65-94. http://dx.doi.org/10.1037/0033-2909.133.1.65

Stewart, M., Stott, T., \& Nuttall, A. (2015). Study goals and procrastination tendencies at different stages of the undergraduate degree. Studies in Higher Education, 1-17. doi:http://dx.doi.org/10.1080/03075079.2015.1005590

Swart, A. J., Lombard, K., \& Jager, H. d. (2010). Exploring the relationship between time management skills and the academic achievement of African engineering students - a case study. European Journal of Engineering Education, 35(1), 79-89. Retrieved from http://dx.doi.org/10.1080/03043790903480316

Şirin, E. F. (2011). Academic procrastination among undergraduates attending school of physical education and sports: Role of general procrastination, academic motivation and academic self-efficacy. Educational Research and Reviews, 6(5), 447-455.

Van Eerde, W. (2003). Procrastination at work and time management training. The Journal of Psychology, 137(5), 421-434. Retrieved from http://dx.doi.org/10.1080/00223980309600625

Walliman, N. (2006). Social research methods. London: SAGE Publications. doi:http://dx.doi.org/10.4135/9781849209939

Yavaş, Ü., Öztürk, G., Açıkel, C. H., \& Özer, M. (2012). Tıp fakültesi öğrencilerinin zaman yönetimi becerilerinin değerlendirilmesi. TAF Preventive Medicine Bulletin, 11(1), 5-10.

Yazıcıoğlu, Y., \& Erdoğan, S. (2011). SPSS Uygulamalı Bilimsel Araştırma Yöntemleri (3. ed.). Ankara: Detay Yayıncilik.

You, J. W. (2015). Examining the effect of academic procrastination on achievement using $1 \mathrm{~ms}$ data in e-learning. Educational Technology \& Society, 18(3), 64-74.

Zekioğlu, A., Erdoğan, N., \& Türkmen, M. (2015). Sporcu öğrencilerin zaman yönetimi becerileri ve akademik başarilari arasindaki ilişki. ULUSLARARASI HAKEMLI PSIKIYYATRI VE PSIKOLOJI ARAŞTIRMALARI DERGISI(4), 24-37.

This work is licensed under a Creative Commons Attribution 3.0 License. 